\title{
HUBUNGAN PENGETAHUAN REMAJA PUTRI TENTANG ANEMIA DENGAN PERILAKU PENCEGAHAN ANEMIA PADA SAAT MENSTRUASI DI SMK NUSA BHAKTI KOTA SEMARANG
}

\author{
THE RELATION BETWEEN TEENAGER'S KNOWLEDGE ABOUT ANEMIA AND THEIR \\ BEHAVIOUR TO PREVENT ANEMIA WHEN THEY HAVE MENSTRUATION ON SMK \\ NUSA BHAKTI SEMARANG
}

\author{
Sri Mularsih \\ Akademi Kebidanan Abdi Husada Semarang \\ Email : srimularsih88@gmail.com
}

\begin{abstract}
ABSTRAK
Remaja putri rentan terkena anemia. Adanya siklus menstruasi setiap bulan merupakan salah satu faktor penyebab remaja putri mudah terkena anemia lebih-lebih didorong oleh pengetahuan mereka yang kurang tentang anemia . Berdasarkan studi pendahuluan dari 10 remaja putri, sebagian besar remaja putri mempunyai pengetahuan yang rendah tentang anemia, selain itu remaja putri juga belum mempunyai perilaku yang baik untuk mencegah anemia seperti konsumsi tablet tambah darah, pengaturan pola makan tinggi zat besi, dan konsumsi minuman yang menghambat penyerapan zat besi. Kondisi ini mendorong penulis melakukan penelitian untuk pengetahuan remaja putri tentang anemia dengan perilaku pencegahan anemia pada saat menstruasi di SMK Nusa Bhakti Semarang. Penelitian ini adalah penelitian korelasi. Menggunakan rancangan penelitian cross sectional. Populasi penelitian ini adalah remaja putri SMK Nusa Bhakti Semarang sebanyak 155 responden dengan teknik sampling menggunakan purposive sampling dengan sampel sebanyak 61 responden. Cara pengumpulan data yaitu dengan data primer dan data sekunder. Analisis univariat dilakukan dengan cara mendeskripsikan tiap variabel, sedangkan analisis data bivariat dilakukan dengan uji Chi Square dan menggunakan program SPSS for window versi 16.0 Pengetahuan remaja yang kurang tentang anemia sebanyak 40 remaja $(65,6 \%)$, perilaku yang tidak mendukung terhadap pencegahan anemia sebanyak 36 remaja (59\%). Hasil penelitian mendapatkan nilai $P=0,000$, dengan demikian Ho ditolak dan Ha diterima yang berarti penelitian ini menunjukkan adanya hubungan signifikan antara pengetahuan remaja putri tentang anemia dengan perilaku pencegahan anemia pada saat menstruasi di SMK Nusa Bhakti Semarang. Perlunya peningkatan pengetahuan remaja putri tentang anemia untuk pencegahan anemia pada saat menstruasi. Peran dari tenaga kesehatan, pemerintah setempat, dan institus i kesehatan terkait untuk melakukan peningkatan kesehatan terkait pencegahan anemia pada saat menstruasi pada remaja putri.
\end{abstract}

Kata Kunci : Hubungan, pengetahuan, perilaku, anemia

\section{ABSTRACT}

Tenager is susceptible to get anemia. It caused by menstruation cycle monthly especially for them who have not knowledge about it yet. Based on the previous research of 10 teenagers, most of them have no experience about anemia besides they have not good behavior to prevent anemia such as taking ferum regularly, dieting and decreasing beverage that blocking serum to be absorbed. These situations encourage the writer to make a research of relation between teenager's knowledge about anemia and their behavior to prevent anemia in their period. This is a correlation research. Use cross sectional design. The populations of the research are 155 girls of SMK Nusa Bhakti Semarang and use purposive sampling technique to get 61 samples of respondents. The writer uses a primary data and secondary data. Univariate analysis is to describe every variable. The bivariate analysis use Chi square test and use SPSS for window 16.0 version. Result of the research, there are 40 girls $(65,6 \%)$ that have less knowledge about anemia and 36 girls (59\%) that have not support behavior to prevent anemia when they have got period. The score of $p$ value is 0,000 so that $\mathrm{HO}$ is rejected and Ha is received so there is a relation between teenager's knowledge about anemia and their behavior to prevent anemia when they have menstruation on SMK Nusa Bhakti Semarang. Requirements to increase teenager's knowledge about anemia should be conducted through health education in their school. If the teenagers have good knowledge about anemia, they can implement their behavior to prevent anemia when they have got menstruation.

Key words: the relation, knowledge, behavior, anemia. 


\section{PENDAHULUAN}

Anemia adalah suatu kondisi medis di mana jumlah sel darah merah atau hemoglobin kurang dari normal. Kadar hemoglobin normal umumnya berbeda antara laki-laki dan perempuan. Remaja didefinisikan sebagai masa peralihan dari masa kanak-kanak ke masa dewasa. World Health Organization (WHO) melaporkan bahwa pada tahun 2008 prevalensi masyarakat yang mengalami defisiensi besi sekitar 37\%, serta semakin meningkat seiring dengan pertambahan penduduk. Menurut WHO tahun 2009, 40\% di negara berkembang berkaitan dengan anemia pada masyarakat dan kebanyakan anemia yang terjadi disebabkan oleh defisiensi besi dan perdarahan akut, bahkan tidak jarang keduanya saling berinteraksi. Menurut Survey Kesehatan Rumah Tangga Prevalensi anemia di Indonesia pada masyarakat masih tinggi yaitu sekitar $40,1 \%$.

Departemen kesehatan mencatat bahwa kaum remaja penderita anemia mencapai $45,8 \%$ untuk remaja laki-laki usia 10-14 tahun dan $57,1 \%$ remaja perempuan atau sejumlah 5-6 juta orang menderita anemia.

Dari data Dinas Kesehatan Kota Semarang, sebanyak 234.095 remaja di Semarang 12.100 diantaranya mengalami anemia. Kasus anemia terbanyak terdapat di Puskesmas Manyaran yaitu 870 jiwa . Dari data Puskesmas Manyaran tentang prevalensi anemia remaja putri di sekolah binaan Puskesmas Manyaran yaitu SMK Nusa Bhakti dan SMK Dian Kartika bulan Januari adalah 35 siswi, Februari 32 siswi, Maret 32 siswi, April 14 siswi, Mei 19 siswi, dan Juni 16 siswi.

Dari studi pendahuluan yang dilakukan pada 10 responden di SMA binaan Puskesmas Manyaran yaitu SMK Dian Kartika dan SMK Nusa Bhakti, didapatkan hasil sebagai berikut: di SMK Dian Kartika Semarang dari 10 responden terdapat 1 remaja putri dengan pengetahuan tentang anemia kurang, 2 remaja putri mempunyai pengetahuan yang cukup tentang anemia, dan 7 remaja putri mempunyai pengetahuan yang baik tentang anemia. Sedangkan di SMK Nusa Bhakti Semarang dari 10 responden terdapat 5 remaja putri dengan pengetahuan tentang anemia kurang, 3 remaja putri mempunyai pengetahuan yang cukup tentang anemia, dan 2 remaja putri mempunyai pengetahuan yang baik tentang anemia. Responden juga belum mempunyai perilaku yang baik untuk mencegah anemia.. Berdasarkan uraian di atas peneliti memutuskan untuk mengambil judul: Hubungan Tingkat Pengetahuan Remaja Puteri tentang Anemia dengan Perilaku Pencegahan Anemia pada Saat Menstruasi di SMK Nusa Bhakti Kota Semarang.

\section{METODE PENELITIAN}

Penelitian ini menggunakan rancangan cross sectional. Jenis penelitian ini termasuk penelitian deskriptif analitik, yaitu mendeskripsikan tiap variabel, kemudian menganalisa hubungan antar variabel. Menurut sifat dasar penelitian, penelitian ini termasuk penelitian survey. Populasi dalam penelitian ini adalah seluruh siswi kelas X dan XI SMK Nusa Bhakti Kota Semarang sebanyak 155 siswi. Sampel adalah sebagian atau wakil populasi yang diteliti (Arikunto, 2010). Rumus untuk menentukan besarnya sampel (Notoatmodjo, 2007) :

$$
\mathrm{n}=\frac{N}{1+N\left(d^{2}\right)}=60,78
$$

Sehingga sampel yang diperlukan dalam penelitian ini adalah 61 siswi. Teknik sampling dalam penelitian ini adalah purposive sampling yaitu melalui penetapan kriteria inklusi dan kriteria eksklusi.

\section{HASIL DAN PEMBAHASAN}

1. Karakteristik Responden Berdasarkan Umur

Berdasarkan hasil penelitian yang telah dilakukan, umur responden dapat dideskripsikan sebagai berikut: 
Tabel 1. Tabel Karakteristik Responden Berdasarkan Umur Siswi SMK Nusa Bhakti Kota Semarang

\begin{tabular}{lcc}
\hline Umur & Frek. & Prosentase (\%) \\
\hline 16 & 22 & 36,1 \\
17 & 17 & 27,9 \\
18 & 14 & 23,0 \\
19 & 8 & 13,0 \\
\hline Jumlah & 61 & 100 \\
\hline
\end{tabular}

Tabel 1. menunjukkan bahwa sebagian besar umur responden adalah 15 tahun yaitu 22 responden $(36,1 \%)$.

2. Analisis Univariat

a. Tingkat Pengetahuan Remaja Putri Tentang Anemia di SMK Nusa Bhakti Kota Semarang .

Berdasarkan hasil penelitian yang telah dilakukan, tingkat pengetahuan remaja putri tentang anemia dapat dideskripsikan sebagi berikut:

Tabel 2. Tabel Tingkat Pengetahuan Remaja Putri tentang Anemia di SMK Nusa Bhakti Kota Semarang

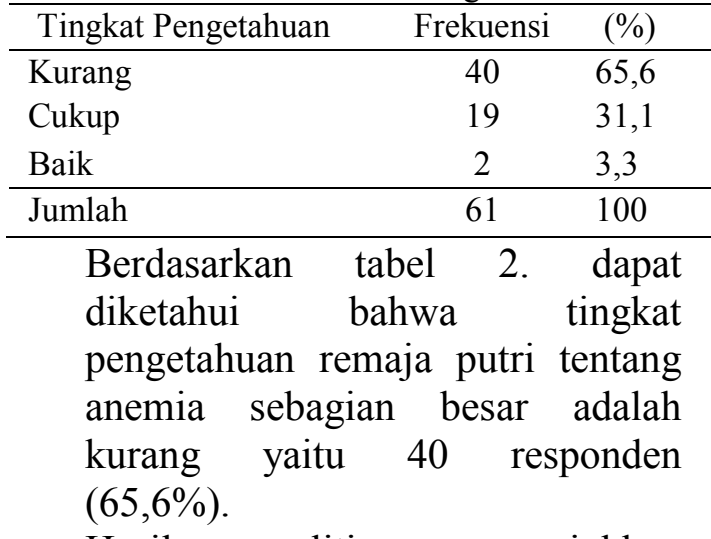

Hasil penelitian menunjukkan bahwa siswi yang memiliki tingkat pengetahuan tentang anemia dengan kategori kurang lebih banyak dari keseluruhan responden yaitu 40 responden $(65,6 \%)$. Responden yang memiliki pengetahuan tentang anemia cukup yaitu 19 responden $(31,3 \%)$ sedangkan responden dengan pengetahuan tentang anemia baik sebanyak 2 responden (3,3\%). Responden dengan pengetahuan baik hanya 2 responden karena di SMK Nusa Bhakti tidak pernah mendapatkan pendidikan kesehatan tentang anemia, sehingga remaja putri tidak mengatahui tentang pencegahan anemia pada saat menstruasi.

Menurut Wawan dan Dewi (2010) faktor-faktor yang dapat mempengaruhi pengetahuan adalah factor pendidikan, pekerjaan, umur, lingkungan, dan social budaya. Responden dalam penelitian ini sudah mendapatkan pendidikan tentang kesehatan reproduksi namun belum mendapatkan pendidikan tentang anemia pada remaja. Hal ini juga disebabkan oleh informasi yang responden terima tidak lengkap atau tidak menyeluruh. Informasi juga memberikan pengaruh terhadap pengetahuan seseorang. Meskipun orang tersebut memiliki pendidikan yang rendah, tapi jika mendapatkan informasi yang baik dari media massa seperti televise, radio, atau surat kabar maka hal itu akan meningkatkan pengetahuan seseorang. Remaja putri perlu mendapatkan pengetahuan pencegahan anemia pada saat menstruasi misalnya melalui pendidikan kesehatan di sekolah, media massa, atau melalui konseling di fasilitas kesehatan.

Usia yang cukup matang dapat membuat seseorang lebih baik dalam menanggapai suatu objek atau masalah. Bertambahnya umur seseorang dapat berpengaruh pada pengetahuan yang diperolehnya, akan tetapi pada umur-umur tertentu atau menjelang usia lanjut kemampuan penerimaan atau mengingat suatu pengetahuan akan berkurang. Pengalaman merupakan sumber suatu pengetahuan, atau pengalaman itu merupakan suatu cara untuk memperoleh kebenaran pengetahuan. Pengalaman pribadi dapat digunakan sebagai suatu upaya untuk memperoleh suatu 
pengetahuan, seseorang yang lebih dewasa dipercaya dari orang yang belum tinggi kedewasaannya. Hal ini sebagai pengalaman dan kematangan jiwa. Dilakukan dengan cara mengulang kembali pengalaman yang diperoleh dalam memecahkan masalah yang dihadapi pada masa lalu.

b. Perilaku Pencegahan Anemia pada Saat Menstruasi di SMK Nusa Bhakti Kota Semarang

Berdasarkan hasil penelitian yang telah dilakukan, perilaku pencegahan anemia pada saat menstruasi dapat dideskripsikan sebagai berikut:

Tabel 3. Perilaku Pencegahan Anemia pada Saat Menstruasi di SMK Nusa Bhakti Kota Semarang .

\begin{tabular}{lcc}
\hline $\begin{array}{l}\text { Perilaku Pencegahan } \\
\text { Anemia }\end{array}$ & Frekuensi & (\%) \\
\hline Mendukung & 25 & 41,0 \\
Tidak Mendukung & 36 & 59,0 \\
\hline Jumlah & 61 & 100
\end{tabular}

Berdasarkan tabel 3. menunjukkan bahwa perilaku pencegahan anemia pada saat menstruasi sebagian besar adalah tidak mendukung yaitu 36 responden atau $(59 \%)$.

Hasil penelitian menunjukkan bahwa sebagian besar siswi memiliki perilaku tidak mendukung dalam pencegahan anemia pada saat menstruasi yaitu sebanyak 36 siswi $(59,0 \%)$ dan yang memiliki perilaku mendukung sebanyak 25 siswi $(41,0 \%)$.

Menurut Soebroto (2009), perilaku untuk mencegah anemia pada saat menstruasi adalah dengan mengkonsumsi makanan dengan gizi seimbang dan tinggi zat besi, serta mengkonsumsi tablet besi pada saat menstruasi.

Remaja putri di SMK Nusa Bhakti Kota Semarang tidak mengkonsumsi tablet besi pada saat menstruasi dan tidak makan dengan gizi seimbang karena sebagian besar dari mereka menkhawatirkan perubahan berat badan, sehingga perilaku mereka untuk mencegah anemia sebagian besar tidak mendukung.

Menurut Notoatmodjo (2010) faktor-faktor yang mempengaruhi perilaku individu dalam pemeliharaan dan peningkatan kesehatan dipengaruhi oleh beberapa faktor yaitu pengetahuan dan sikap masyarakat, tingkat pendidikan, tingkat ekonomi sosial, sarana dan prasarana atau fasilitas kesehatan, jarak lokasi, biaya, sumber daya, dan perilaku tokoh masyarakat, tokoh agama, termasuk petugas kesehatan.

Responden sebagian besar memiliki perilaku tidak mendukung dalam pencegahan anemia pada saat menstruasi karena pengetahuan responden tentang anemia sebagian besar kurang baik. Dari keseluruhan responden yaitu 40 responden $(65,6 \%)$ memiliki pengetahuan kurang. Responden yang memiliki pengetahuan tentang anemia cukup yaitu 19 responden atau $(31,3 \%)$ sedangkan responden dengan pengetahuan tentang anemia baik sebanyak 2 responden (3,3\%). Untuk mendapatkan perilaku mendukung dalam pencegahan anemia pada saat menstruasi, pengetahuan remaja putri tentang anemia perlu ditingkatkan karena pengetahuan merupakan faktor yang mempengaruhi perilaku individu dalam peningkatan dan pemeliharaan kesehatan.

3. Analisis Bivariat

Hubungan pengetahuan remaja putri tentang anemia dengan perilaku pencegahan anemia pada saat menstruasi:

Tabel 4. Tabel Silang Hubungan Pengetahuan Remaja Putri tentang Anemia dengan Perilaku Pencegahan Anemia pada Saat Menstruasi. 


\begin{tabular}{lcccccc}
\hline \multirow{2}{*}{$\begin{array}{c}\text { Tingkat } \\
\text { Pengetahuan }\end{array}$} & \multicolumn{6}{c}{ Perilaku Pencegahan Anemia } \\
\cline { 2 - 7 } & $\begin{array}{c}\text { Tidak } \\
\text { Mendukung }\end{array}$ & \multicolumn{2}{c}{ Mendukung } & \multicolumn{2}{l}{ Total } \\
\cline { 2 - 7 } & $\mathrm{f}$ & $\%$ & $\mathrm{f}$ & $\%$ & $\mathrm{f}$ & $\%$ \\
\hline Kurang & 28 & 45,9 & 12 & 19,7 & 40 & 65,6 \\
Cukup & 8 & 13,1 & 11 & 18,0 & 19 & 31,1 \\
Baik & 0 & 0 & 2 & 3,3 & 2 & 3,3 \\
\hline Total & 36 & 59,0 & 25 & 41,0 & 61 & 100 \\
\hline
\end{tabular}

Tabel 4. menunjukkan sebagian responden memiliki tingkat pengetahuan yang kurang tentang anemia dengan perilaku pencegahan anemia tidak mendukung yaitu 28 responden $(45,9 \%)$.

Tabel 5. Tabel Silang hasil penggabungan sel tingkat pengetahuan

\begin{tabular}{|c|c|c|c|c|c|}
\hline \multirow{3}{*}{$\begin{array}{l}\text { Tingkat } \\
\text { Pengetahu } \\
\text { an }\end{array}$} & \multicolumn{5}{|c|}{ Perilaku Pencegahan Anemia } \\
\hline & \multicolumn{2}{|c|}{$\begin{array}{c}\text { Tidak } \\
\text { Mendukung }\end{array}$} & \multicolumn{2}{|c|}{ Mendukung } & Total \\
\hline & $\mathrm{f}$ & $\%$ & $\mathrm{f}$ & $\%$ & $\mathrm{f}$ \\
\hline Kurang & 28 & 45,9 & 12 & 19,7 & 40 \\
\hline $\begin{array}{l}\text { Cukup + } \\
\text { Baik }\end{array}$ & 8 & 13,1 & 13 & 21,3 & 21 \\
\hline Total & 36 & 59,0 & 25 & 41,0 & 61 \\
\hline
\end{tabular}

Berdasarkan hasil tabel silang dari 61 responden terdapat 36 responden $(59 \%)$ dengan perilaku tidak mendukung terhadap pencegahan anemia. Pengetahuan kurang lebih besar daripada pengetahuan cukup+baik yaitu 28 responden $(45,9 \%)$ sedangkan pengetahuan cukup+baik sebanyak 8 responden (13,1\%). Perilaku mendukung terhadap pencegahan anemia sebanyak 25 responden (41\%), dengan pengetahuan kurang sebanyak 12 responden $(19,7 \%)$ dan pengetahuan cukup+baik sebanyak 13 responden $(21,3 \%)$. Total pengetahuan responden kurang sebanyak 40 responden $(65,6 \%)$ dan pengetahuan cukup+baik sebanyak 21 responden $(34,4 \%)$.

Berdasarkan hasil pengujian dengan SPSS nilai $p$ value sebesar 0,016 sehingga lebih kecil dari 0,05. Hal ini berarti Ho ditolak dan $\mathrm{Ha}$ diterima, maka dapat disimpulkan bahwa ada hubungan pengetahuan remaja putri tentang anemia dengan perilaku pencegahan anemia pada saat menstruasi di SMK Nusa Bhakti Kota Semarang.

Berdasarkan hasil tabel silang, responden yang memiliki pengetahuan tentang anemia baik cenderung memiliki perilaku mendukung dalam pencegahan anemia pada saat menstruasi. Responden yang memiliki pengetahuan tetang anemia kurang, cenderung memiliki perilaku tidak mendukung dalam pencegahan anemia pada saat mentruasi. Hal tersebut menunjukan adanya kecenderungan pengetahuan remaja putri tentang anemia berhubungan dengan perilaku pencegahan anemia pada saat menstruasi. Kecenderungan dan $\%$ hubungan itu telah dibuktikan dengan ${ }_{6}^{6}$ uji Chi Square menggunakan SPSS 64 windows versi 16.0 Menurut 4 Notoatmodjo (2010), Pengetahuan 10dipengaruhi oleh berbagai faktor, antara 0 lain factor umur, pekerjaan, pendidikan, lingkungan, dan budaya.

Siswi yang mempunyai pengetahuan tentang anemia yang kurang baik adalah salah satu penyebab perilaku tidak mendukung dalam pencegahan anemia pada saaat menstruasi. Pengetahuan yang kurang disebabkan karena siswi tidak memahami atau hanya menerima informasi yang tidak menyeluruh. Pengetahuan seseorang mempengaruhi perilaku seseorang misalnya perilaku pencegahan anemia pada saat menstruasi. Pengetahuan tentang anemia perlu ditingkatkan untuk meningkatkan perilaku pencegahan anemia pada saat menstruasi.

\section{KESIMPULAN}

Karakteristik responden yaitu umur responden adalah 15 sampai 18 tahun. Sebagian besar umur responden adalah 15 tahun $(36,1 \%)$, Pengetahuan remaja putri SMK Nusa Bhakti Semarang tentang anemia kurang yaitu 40 responden $(65,6 \%)$, Perilaku siswi tidak mendukung 
pada pencegahan anemia pada saat menstruasi di SMK Nusa Bhakti Semarang yaitu 36 responden (59\%), Ada hubungan positif dan signifikan antara pengetahuan remaja putri tentang anemia dengan perilaku pencegahan anemia pada saat menstruasi .

\section{DAFTAR PUSTAKA}

Aditian,N.2009. Faktor-faktor yang mempengaruhi Anemia Remaja Putri.Jakarta: FKM UI.

Anurogo, Dito. 2011. Cara Jitu Mengatasi Nyeri Haid. Yogyakarta: Andi Offset.

Alimul Hidayat, Aziz. 2010. Metode Penelitian Kebidana dan Teknik Analisis Data. Jakarta: Salemba Medika.

Arikunto. 2010. Prosedur Penelitian Suatu Pendekatan Praktik. Jakarta: Rineka Cipta.

Arsyak. Hubungan Tingkat Pengetahuan Remaja dengan Perilaku Pencegahan Anemia (www. usu.ac.id). Diakses pada 20 Oktober 2012.

Arsyak. Gambaran Sikap dan Pengetahuan Remaja Putri tentang Anemia (www. usu. ac.id). Diakses pada 20 Oktober 2012.

Azwar, Saifudim. 2009. Metode Penelitian. Yogyakarta: Pustaka Pelajar Offset.

Dahlan, S. 2004. Statistika untuk Kedokteran dan Kesehatan. Jakarta: Bina Mitra Press.

Departemen Kesehatan. Pedoman Penanggulangan untuk Anemia Gizi untuk Remaja Putri dan Wanita Usia Subur (gizi.depkes.go.id/anemia). Diakses pada 10 November 2012.

Fitriani, Khurnia. Hubungan Pengetahuan Remaja Putri tentang Anemia dengan Sikap Terhadap Anemia di SMA Negeri I Petanahan Kec. Petanahan Kabupaten Kebumen Tahun 2011 (http://www.digilib.stikesmuhgombong .ac.id). Diakses pada 22 Oktober 2012.
Ikatan Dokter Anak Indonesia. 2002. Tumbuh Kembang Anak Remaja. Jakarta: Sagung Seto.

Nirwana, Benih Ade. 2011. Psikologi Kesehatan Wanita. Yogyakarta: Nuha Medika.

Notoatmodjo, Soekidjo. 2010. Ilmu Perilaku Kesehatan. Jakarta: Rineka Cipta.

Notoatmodjo, Soekidjo. 2010. Metodologi Penelitian Kesehatan. Jakarta: Rineka Cipta.

Notoatmodjo, Soekidjo. 2010. Promosi Kesehatan dan Ilmu Perilaku. Jakarta: Rineka Cipta.

Proverawati, Atikah. 2011. Anemia dan Anemia Kehamilan. Yogyakarta: Nuha Medika.

Proverawati, Atikah. 2009. Menarche Menstruasi Pertama Penuh Makna. Yogyakarta: Nuha Medika.

Prawiroharjo, Sarwono. Ilmu Kandungan. 2009. Jakarta: Yayasan Bina Pustaka Sarwono Prawiroharjo.

Soebroto, Ikhsan.2009. Cara Mudah Mengatasi Problem Anemia. Yogyakarta: Glossia Media.

Wawan dan Dewi. 2010. Teori dan Pengukuran Pengetahuan Sikap dan Perilaku Manusia. Yogyakarta: Nuha Medika.

Wulan, Arum. Peningkatan Pengetahuan Siswa tentang Anemia Melalui Penyuluhan (http://digilib.unimus.ac.id). Diakses pada 30 Oktober 2011. 